\title{
POTENSI ZONA URAT KUARSA BERDASARKAN ANALISIS GEOFISIKA DENGAN METODE POLARISASI TERINDUKSI DI DAERAH OLAT TANAH MERAH - PLAMPANG, KABUPATEN SUMBAWA, PROVINSI NUSA TENGGARA BARAT
}

\section{POTENTIAL OF QUARTZ VEIN ZONE BASED ON GEOPHYSICAL ANALYSIS USING INDUCED POLARIZATION METHOD AT OLAT TANAH MERAH - PLAMPANG AREA, SUMBAWA DISTRICT, WEST NUSA TENGGARA PROVINCE}

\author{
Ignatius Forza Yoga Gautama1, Dzil Mulki Heditama², dan Yudi Aziz Muttaqin² \\ ${ }^{1}$ Prodi Geofisika, Fakultas Matematika dan IImu Pengetahuan Alam, \\ Universitas Gadjah Mada, Yogyakarta, \\ ${ }^{2}$ Pusat Sumber Daya Mineral, Batubara dan Panas Bumi \\ ignatius.forza@gmail.com
}

\begin{abstract}
ABSTRAK
Penelitian dengan menggunakan metode polarisasi terinduksi telah dilakukan di daerah Olat Tanah Merah - Plampang, Kabupaten Sumbawa, Provinsi Nusa Tenggara Barat. Tujuan dari penelitian ini adalah untuk mengetahui sebaran dan potensi zona urat kuarsa yang diduga mengandung mineralisasi emas di bawah permukaan. Pengukuran metode polarisasi terinduksi dilakukan dalam kawasan waktu menggunakan konfigurasi dipol-dipol dengan jarak antar elektroda $50 \mathrm{~m}$. Data polarisasi terinduksi yang terukur sebanyak 14 lintasan dengan panjang tiap lintasan $1000 \mathrm{~m}$ dan jarak antar lintasan $100 \mathrm{~m}$ s.d. $200 \mathrm{~m}$. Pemodelan 2D dilakukan untuk mendapatkan penampang dengan nilai resistivitas dan chargeability dari tiap lintasan, sedangkan pemodelan 3D dilakukan untuk mengetahui arah kemenerusan zona mineralisasi emas dan memperkirakan potensi volume zona urat kuarsa. Berdasarkan hasil penampang $2 \mathrm{D}$ resistivitas dan chargeability, diketahui bahwa zona mineralisasi emas memiliki nilai resistivitas $>250 \Omega \mathrm{m}$ dan chargeability $>300 \mathrm{~ms}$ yang diinterpretasikan sebagai mineral-mineral sulfida yang berasosiasi dengan bijih emas dan alterasi argilik - silisik pada batuan tuf dan diorit. Berdasarkan hasil model 3D diketahui adanya kemenerusan zona mineralisasi emas utama yang memanjang dengan arah utara-selatan dan volume zona urat kuarsa yang mengandung mineralisasi emas diperkirakan sebesar $519.000 \mathrm{~m}^{3}$.
\end{abstract}

Kata kunci: polarisasi terinduksi, resistivitas, chargeability, mineralisasi, emas

\section{ABSTRACT}

Research using induced polarization method has been carried out at Olat Tanah Merah Plampang area, Sumbawa District, West Nusa Tenggara Province. The purpose of this research is to determine the distribution and potential of quartz vein zone which contains gold mineralization in subsurface. Induced polarization measurement was taken in time domain using dipole-dipole configuration and the distance between electrodes was $50 \mathrm{~m}$. The induced polarization dataset had 14 lines with each line length was $1000 \mathrm{~m}$ and the distance between lines was $100 \mathrm{~m}-200 \mathrm{~m}$. 2D modeling was done to obtain section of resistivity and chargeability of each line, therefore 3D modeling was done to determine the direction of gold mineralization zone and estimate the volume potential of quartz vein zone. Based on $2 D$ resistivity and chargeability section results, the gold mineralization zones have resistivity values $>250 \Omega m$ and chargeability values $>300$ ms interpreted as sulfide minerals associated with gold ore and argillic - silicic alterations in tuff and diorite rocks. Based on 3D model results, the main zone of gold mineralization extends north-south direction and the volume of quartz vein zone which contains gold mineralization is estimated at $519.000 \mathrm{~m}^{3}$.

Keywords: induced polarization, resistivity, chargeability, mineralization, gold 


\section{PENDAHULUAN}

Di daerah Plampang ditemukan urat-urat yang terindikasi mengandung emas dengan ketebalan sekitar $10 \mathrm{~cm}$ s.d 25 $\mathrm{cm}$. Kehadiran urat kuarsa tersebut menjadi indikasi terjadinya proses hidrotermal yang berasosiasi dengan mineralisasi logam. Mineralisasi ditemukan pada batuan tuf dan diorit yang mengandung mineral sulfida seperti pirit, kalkopirit, sfalerit, bornit, dan kovelit. Daerah prospek mineralisasi emas diketahui dari hasil kegiatan eksplorasi yang dilakukan oleh Pusat Sumber Daya Geologi pada tahun 2013. Lokasi prospek berada di Olat Tanah Merah, Dusun Teluk Santong, Kecamatan Plampang, Kabupaten Sumbawa, Provinsi Nusa Tenggara Barat (Moetamar, 2013). Di daerah tersebut juga terdapat penambangan emas secara tradisional oleh masyarakat sekitar.

Proses pembentukan emas berawal dari fluida panas yang berasal dari dalam bumi. Fluida panas tersebut naik ke permukaan melalui celah atau rekahan pada struktur batuan kemudian mengalami proses pengendapan. Pengendapan yang terjadi pada struktur batuan membuat emas tidak mengendap di satu tempat saja, melainkan letaknya tersebar. Emas dalam lingkungan pengendapannya memiliki kandungan dengan nilai bervariasi.

Keadaan tersebut mempersulit kegiatan eksplorasi dalam melokalisir keberadaan mineralisasi emas. Oleh karena itu perlu dilakukan eksplorasi dengan metode geofisika untuk menggambarkan struktur di bawah permukaan bumi dan mengidentifikasi sebaran, bentuk, dan dimensi zona mineralisasi emas. Salah satu metode geofisika yang sangat sering digunakan dalam eksplorasi emas adalah metode polarisasi terinduksi (IP -Induced Polarization).

Metode IP merupakan pengembangan dari metode resistivitas (Telford dkk., 1990). Prinsip dasar pengukuran metode ini dilakukan dengan cara mengalirkan arus ke dalam permukaan bumi. Ketika arus listrik dialirkan, maka timbul beda potensial $(\Delta \mathrm{V})$. Ketika arus listrik dimatikan, seharusnya beda potensial yang terukur bernilai nol. Namun karena sifat medium yang polarizable, nilai beda potensial yang terukur tidak langsung menjadi nol, namun turun secara perlahan-lahan yang disebut dengan overvoltage effect (Reynolds, 2011). Hal itu menjadi sebuah parameter dalam metode ini yang disebut sebagai parameter chargeability.

Metode IP merupakan metode geofisika yang banyak digunakan untuk mengetahui sebaran mineral sulfida yang berasosiasi dengan emas, perak, besi, dan bijih mineral logam lainnya. Data metode IP digunakan untuk membuat suatu model berdasarkan parameter data resistivitas dan chargeability. Tujuan dari penelitian ini yaitu untuk mengetahui sebaran dan potensi zona urat kuarsa di bawah permukaan yang diduga mengandung mineralisasi emas.

\section{METODOLOGI}

Metode pengukuran yang dilakukan pada penelitian ini adalah metode IP dalam kawasan waktu dengan konfigurasi dipoldipol. Pengukuran ini memiliki 14 lintasan (lintasan A s.d. lintasan N) dengan panjang tiap lintasan $1000 \mathrm{~m}$ dan berarah timurlautbaratdaya. Jarak antar elektroda pengukuran $50 \mathrm{~m}$, sedangkan jarak antar lintasan $100 \mathrm{~m}$ s.d. $200 \mathrm{~m}$. Pengukuran menggunakan nilai $\mathrm{n}$ maksimal adalah $\mathrm{n}=$ 7. Hasil pengukuran di lapangan berupa data beda potensial $(\Delta \mathrm{V})$, arus $(\mathrm{I})$, resistivitas $(\Omega m)$, chargeability $(\mathrm{M})$ dan topografi.

Proses inversi dilakukan terhadap data lapangan dengan tujuan untuk mengestimasi parameter fisis batuan yang tidak diketahui sebelumnya (Supriyanto, 2007). Parameter yang dihasilkan dari inversi $2 \mathrm{D}$ adalah nilai true resistivity dan true chargeability. Hasil penampang 2D dapat digunakan untuk mengidentifikasi zona sebaran mineralisasi emas. 
Kemudian dilakukan pemodelan 3D berdasarkan data hasil inversi 2D. Pemodelan 3D yang dibuat merupakan korelasi nilai resistivitas dan chargeability semua lintasan sehingga dapat dilihat dengan jelas kemenerusan zona mineralisasi emas. Hasil dari model korelasi ini adalah diketahuinya pola sebaran nilai resistivitas dan chargeability yang dapat mengindikasikan kemenerusan zona mineralisasi emas.

Selanjutnya dilakukan perhitungan volume urat-urat kuarsa yang diduga mengandung mineralisasi emas berdasarkan nilai resistivitas dan chargeability. Perhitungan volume tersebut dilakukan dengan cara menghitung volume dari nilai cut off berdasarkan nilai resistivitas dan chargeability yang ditentukan sebelumnya. Pemodelan 3D ini dilakukan dengan tipe pemodelan Solid Modelling menggunakan pilihan Directional Weighting sehingga dapat memodelkan zona mineralisasi yang dominan berkembang ke arah tertentu. Diagram alir penelitian ditunjukkan pada Gambar 1.

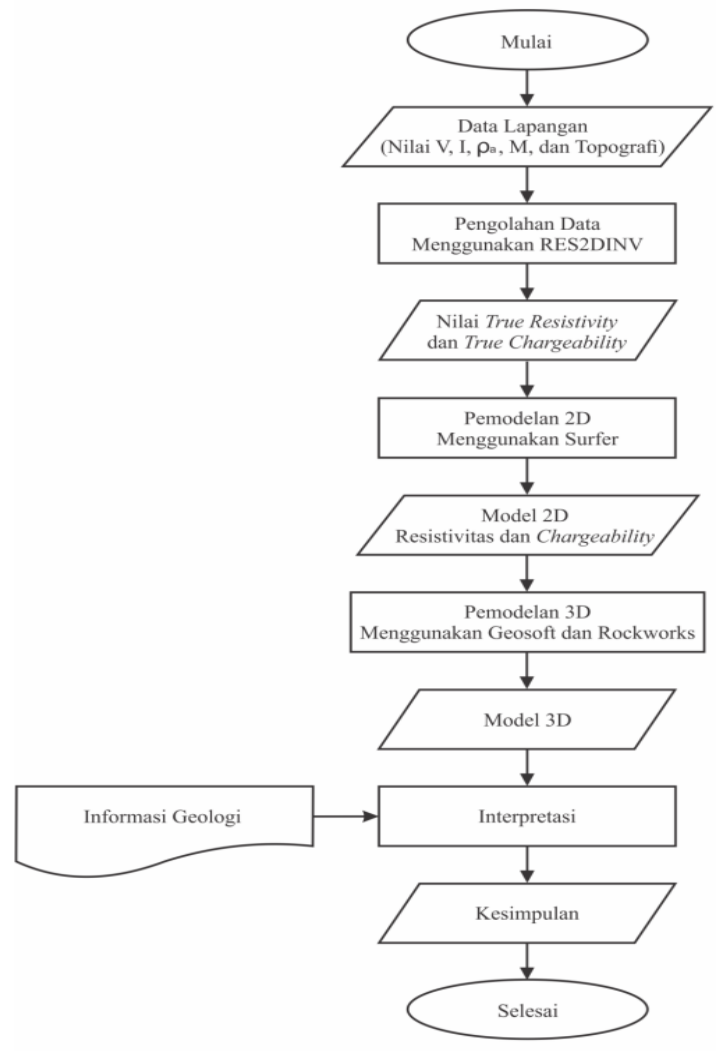

Gambar 1. Diagram alir penelitian

\section{GEOLOGI}

\section{Geologi Regional}

Pulau Sumbawa yang berada di kepulauan Nusa Tenggara terletak di bagian timur Busur Sunda atau di zona transisi dalam sistem busur kepulauan Sunda-Banda (Sjoekri, 1980). Busur kepulauan Sunda-Banda merupakan gabungan dari beberapa sistem busur magmatik, yaitu Busur Sunda ke arah barat dan Busur Banda ke arah timur.

Busur kepulauan Sunda-Banda dihasilkan dari tumbukan antara Lempeng HindiaAustralia dan Lempeng Eurasia (Hamilton, 1973). Pulau Sumbawa dibatasi oleh penunjaman subduksi Jawa di bagian selatan dan Cekungan Flores di bagian utara (Darman dan Sidi, 2000).

Keberadaan subduksi tersebut menimbulkan terbentuknya beberapa gunung api di Pulau Sumbawa. Gunung api tersebut antara lain Gunung Tambora, Gunung Bersanak, Gunung Batulanteh, dan Gunung Malaka. Gunung Tambora merupakan gunung tertinggi di Pulau Sumbawa.

Pulau Sumbawa memanjang dengan arah barat-timur dan terdapat lembah-lembah berarah timurlaut-baratdaya dan baratlaut-tenggara. Teluk Saleh yang merupakan teluk terbesar di pulau tersebut membagi Pulau Sumbawa menjadi dua bagian utama, yaitu Sumbawa Barat dan Sumbawa Timur (Sudrajat dkk., 1998).

\section{Morfologi}

Morfologi daerah penelitian menurut Moetamar (2013) dapat dibagi menjadi dua, yaitu morfologi perbukitan gelombang dan morfologi pedataran. Morfologi perbukitan gelombang berada pada ketinggian $80 \mathrm{mdpl}$ s.d. $150 \mathrm{mdpl}$. Morfologi pedataran berada di daerah pantai yang tidak cukup luas, menempati bagian utara daerah penelitian. 


\section{MAKALAH ILMIAH}

\section{Struktur Geologi}

Struktur geologi yang terdapat di daerah penelitian menurut Moetamar (2013) terdiri dari struktur sesar dan kekar. Sesar ini berada pada bagian utara daerah penelitian. Sesar tersebut memiliki arah $\mathrm{N}$ $330^{\circ}$ s.d $340^{\circ}$ E. Struktur kekar terdapat pada batuan intrusi diorit.

\section{Stratigrafi}

Menurut Moetamar (2013) satuan batuan yang terdapat di daerah penelitian terdiri dari tiga satuan dengan urutan tua ke muda adalah sebagai berikut (Gambar 2).

a. Batuan vulkanik tua

Batuan vulkanik tua yang menjadi basement di daerah penelitian terdiri dari tuf dan breksi vulkanik berumur Miosen Awal terdapat di lereng perbukitan yang menempati sebagian besar daerah penelitian. Batuan ini mengalami alterasi kuat seperti silisifikasi, kaolinisasi, dan limonitisasi pada rekahan dan urat halus. Batuan vulkanik tua mengandung banyak pirit yang letaknya tersebar. Dua zona urat kuarsa mineralisasi emas ditemukan pada lereng punggungan berarah utara-selatan.

b. Batuan intrusi diorit

Diorit merupakan batuan intrusif berwarna abu-abu kehitaman yang mengandung mineral pirit dan berumur Miosen Tengah. Kehadiran batuan ini diduga menjadi penyebab adanya mineralisasi di daerah penelitian. Dari hasil analisis petrografi, batuan mengandung mineral-mineral antara lain, plagioklas, piroksen, klorit, karbonat, opak/oksida besi, kuarsa, dan epidot. c. Batuan vulkanik muda

Komposisinya terdiri dari endapan lahar, tuf, dan lava andesit. Batuan berumur Plistosen dan dijumpai di atas perbukitan yang terjal. $\mathrm{Di}$ daerah punggungan terdapat bongkah batuan lava andesit berukuran $30 \mathrm{~cm}$ s.d. 50 $\mathrm{cm}$, berwarna hitam, dan terlihat masih segar. Pada satuan batuan ini tidak dijumpai adanya mineralisasi.

d. Aluvium

Aluvium terdapat di daerah dataran rendah terdiri dari endapan lumpur, pasir, lempung, kerikil, kerakal, dan bongkah-bongkah batuan vulkanik. Satuan batuan ini berumur Holosen.

\section{Mineralisasi}

Menurut Moetamar (2013) terdapat beberapa mineralisasi dan alterasi yang teramati di daerah penelitian. Mineralisasi ditemukan pada batuan vulkanik tua yang teralterasi kuat dengan alterasi silisifikasi dan argilik. Alterasi argilik dicirikan dengan kehadiran mineral kaolin, monmorilonit, muskovit klorit, dan illite (Rahmah, 2009). Alterasi silisifikasi dicirikan dengan kehadiran mineral kuarsa, kristobalit, kalsedon, dan tridimit.

Pada daerah ini terdapat dua zona urat yang berpasangan, masing - masing zona urat memiliki lebar sekitar $10 \mathrm{~m}$ dan panjang $400 \mathrm{~m}$. Zona urat ini memiliki arah umum utara-selatan ( $335^{\circ}$ s.d. $350^{\circ} \mathrm{E}$ ). Kedua zona urat tersebut berjarak sekitar $250 \mathrm{~m}$. Urat kuarsa tersebut memiliki ketebalan $10 \mathrm{~cm}$ s.d. $25 \mathrm{~cm}$ dengan tekstur vuggy dan comb structure, yang diduga mengandung emas dengan mineral sulfida seperti pirit, kalkopirit, sfalerit, bornit, dan kovelit. 


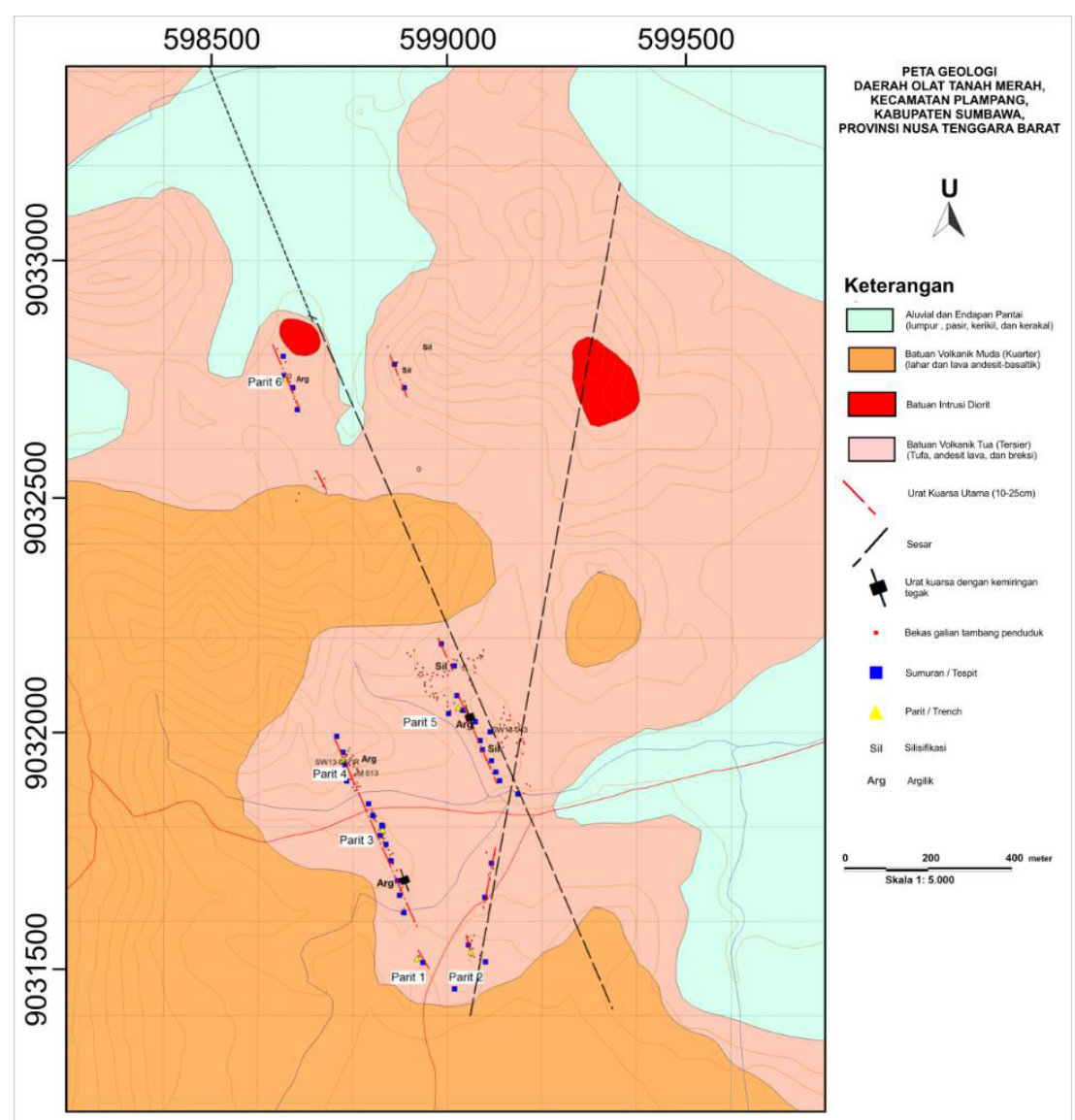

Gambar 2. Peta geologi daerah penelitian (Moetamar, 2013)

\section{HASIL DAN PEMBAHASAN}

Pengolahan data inversi dilakukan dengan memasukkan nilai resistivitas dan chargeability hasil pengukuran di lapangan. Hasil pengolahan data inversi tersebut merupakan model 2D yang menggambarkan distribusi nilai resistivitas dan chargeability yang sebenarnya di bawah permukaan bumi.

Persebaran zona mineralisasi emas dapat ditentukan berdasarkan nilai resistivitas dan chargeability semu yang diperoleh dari pengambilan data di lapangan. Dari data tersebut dilakukan proses inversi untuk mendapatkan nilai resistivitas dan chargeability yang sebenarnya. Proses inversi dilakukan sehingga dihasilkan model berupa penampang 2D berdasarkan parameter model berupa nilai resistivitas dan chargeability.

Lintasan $F$ memotong keterdapatan singkapan mineralisasi emas pada titik 200 $m$ sehingga lintasan ini menjadi acuan interpretasi untuk melokalisir keberadaan zona mineralisasi emas. Zona mineralisasi emas berupa zona urat-urat kuarsa yang mengandung bijih emas. Berdasarkan hasil penampang 2D resistivitas dan chargeability pada Lintasan F (Gambar 3), terlihat respon mineralisasi emas pada titik $200 \mathrm{~m}$ yang ditunjukkan dengan nilai resistivitas $>250 \Omega m$ dan chargeability $300-$ $500 \mathrm{~ms}$. Zona dengan nilai resistivitas dan chargeability tersebut diinterpretasikan sebagai batuan tuf dan diorit sebagai host rock yang mengandung mineralisasi emas.

Selain itu ditemukan juga zona mineralisasi emas lainnya di titik $530 \mathrm{~m}$ s.d. $560 \mathrm{~m}$ pada elevasi - 40 m dengan nilai resistivitas $>500$ $\Omega \mathrm{m}$ dan nilai chargeability $>300 \mathrm{~ms}$. Pada Lintasan $\mathrm{F}$ juga ditemukan keberadaan dua zona alterasi. Zona alterasi pertama pada Lintasan $F$ terdapat di titik $320 \mathrm{~m}$ pada elevasi - $50 \mathrm{~m}$ dengan nilai resistivitas $<10$ $\Omega \mathrm{m}$ dan nilai chargeability $300-500 \mathrm{~ms}$. Zona alterasi kedua terdapat di titik $480 \mathrm{~m}$ 


\section{MAKALAH ILMIAH}

s.d. 530 m pada elevasi - 40 m dengan nilai resistivitas $<100 \Omega \mathrm{m}$ dan nilai chargeability $>300$ ms. Kedua zona alterasi tersebut diinterpretasikan sebagai alterasi argilik yang ditandai dengan nilai resistivitas rendah merupakan batuan vulkanik tua yang terlapukkan.

Dari hasil interpretasi pada penampang $\mathrm{F}$ dapat disimpulkan bahwa batuan intrusi diorit memiliki nilai resistivitas $>500 \Omega \mathrm{m}$. Nilai resistivitas tersebut diklasifikasikan sebagai skala tinggi. Sedangkan batuan tuf memiliki nilai resistivitas $>250 \Omega \mathrm{m}$. Menurut Moetamar (2013) zona mineralisasi ditemukan pada batuan tuf yang diintrusi oleh batuan diorit. Keberadaan kedua jenis batuan tersebut dijadikan zona target penelitian.

Batuan intrusi diorit dan tuf sebagai host rock mineralisasi emas berasosiasi dengan mineral-mineral sulfida lainnya seperti pirit, sfalerit, kalkopirit, bornit dan kovelit. Mineral-mineral tersebut menimbulkan respon nilai chargeability yang tinggi yaitu $>300 \mathrm{~ms}$. Oleh karena itu nilai $>300 \mathrm{~ms}$ diklasifikasikan sebagai skala tinggi yang menjadi zona target penelitian. Nilai resistivitas dan chargeability tersebut dapat diklasifikasikan dalam bentuk skala tertentu yang ditunjukkan pada Tabel 1 dan Tabel 2 di bawah ini.

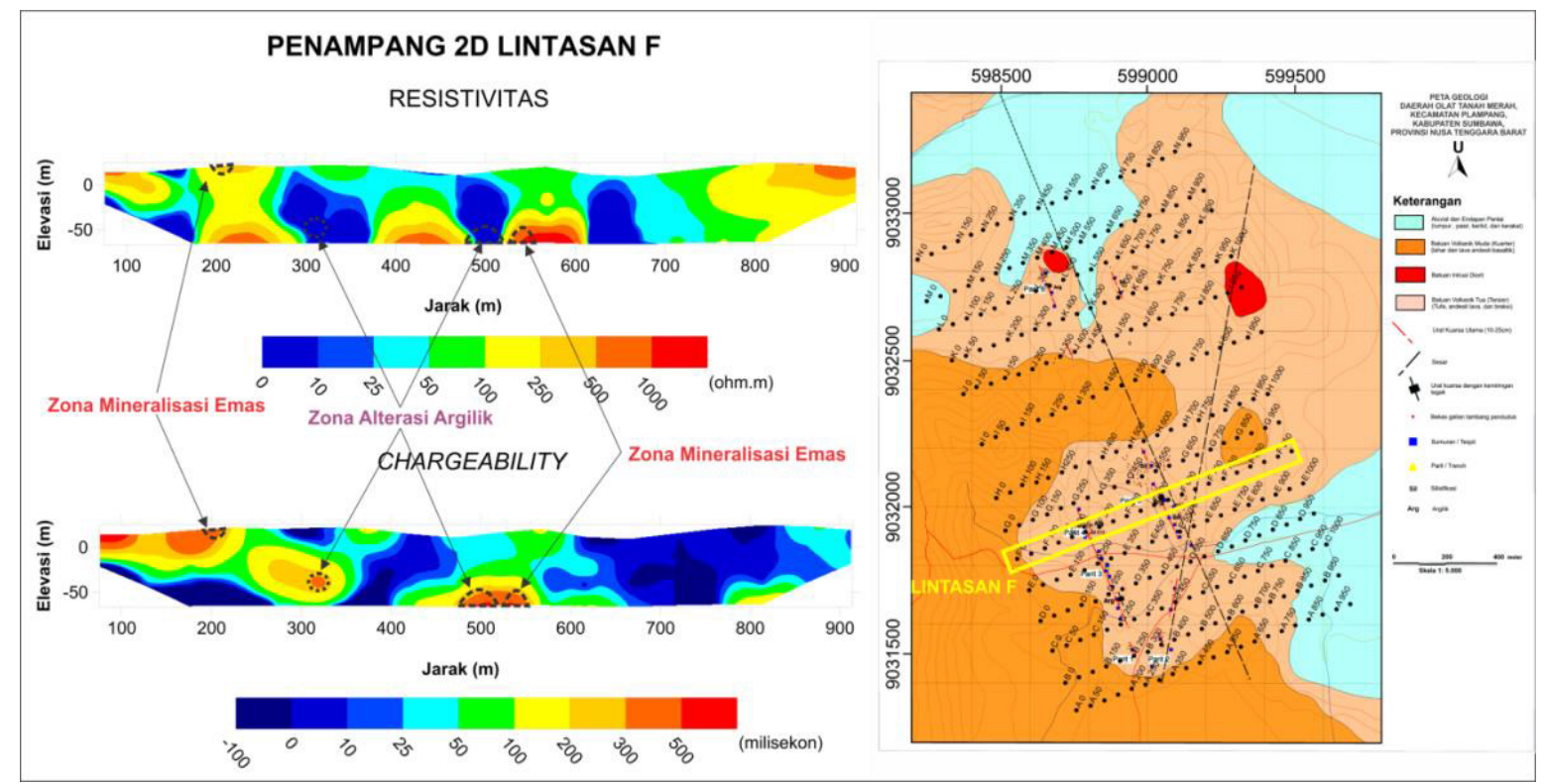

Gambar 3. Hasil interpretasi Lintasan F

Tabel 1. Klasifikasi skala nilai resistivitas dan chargeability

\begin{tabular}{lll}
\multicolumn{1}{c}{ Skala } & \multicolumn{1}{c}{ Resistivitas $(\Omega \mathrm{m})$} & Chargeability $(\mathrm{ms})$ \\
\hline Rendah & $<100$ & $<100$ \\
\hline Sedang & $100-500$ & $100-300$ \\
\hline Tinggi & $>500$ & $>300$ \\
\hline
\end{tabular}

Tabel 2. Acuan interpretasi berdasarkan nilai resistivitas dan chargeability

\begin{tabular}{lll}
\hline \multicolumn{1}{c}{ Interpretasi } & \multicolumn{1}{c}{ Resistivitas } & \multicolumn{1}{c}{ Chargeability } \\
\hline Lempung, Pasir & Rendah & Rendah \\
\hline Tuf & Sedang-Tinggi & Sedang-Tinggi \\
\hline Batuan Intrusi Diorit, Andesit & Tinggi & Sedang-Tinggi \\
\hline Zona Alterasi Argilik & Rendah & Tinggi \\
\hline Zona Alterasi Silisik & Sedang-Tinggi & Tinggi \\
\hline Zona Mineralisasi Emas/Zona Urat Kuarsa & Sedang-Tinggi & Tinggi \\
\hline
\end{tabular}

6 
Berdasarkan Tabel 2 maka dapat dideskripsikan sebagai berikut :

a. Lempung dan pasir dengan nilai resistivitas rendah $(<100 \Omega \mathrm{m})$ dan nilai chargeability rendah $(<100$ $\mathrm{ms}$ ).

b. Tuf dengan nilai resistivitas sedang hingga tinggi $(>250 \Omega \mathrm{m})$ dan nilai chargeability sedang hingga tinggi (>100 ms).

c. Batuan intrusi diorit dan andesit dengan nilai resistivitas tinggi $(>500$ $\Omega \mathrm{m})$ dan nilai chargeability sedang hingga tinggi (>100 ms).

d. Zona alterasi argilik dicirikan dengan nilai resistivitas rendah $(<100 \Omega \mathrm{m})$ dan nilai chargeability tinggi (>300 ms).

e. Zona alterasi silisik dicirikan dengan nilai resistivitas sedang hingga tinggi $(>100 \Omega m)$ dan nilai chargeability tinggi (>300 ms).

f. Zona mineralisasi emas/zona urat kuarsa dicirikan dengan nilai resistivitas sedang hingga tinggi $(>250 \Omega \mathrm{m})$ dan nilai chargeability tinggi (>300 $\mathrm{ms}$ ).

Pengukuran metode IP yang telah dilakukan sebanyak 14 lintasan (Lintasan
A hingga Lintasan N). Dari semua hasil penampang 2D resistivitas dan chargeability tiap lintasan tersebut, diketahui bahwa terdapat 11 lintasan yang teridentifikasi mengandung zona mineralisasi emas. Lintasan tersebut adalah lintasan-lintasan $B, C, D, F, G, H, I$, $\mathrm{K}, \mathrm{L}, \mathrm{M}$, dan $\mathrm{N}$. Hasil interpretasi penampang Lintasan A sampai Lintasan $\mathrm{N}$ selain Lintasan F ditunjukkan pada Gambar 7 s.d. Gambar 19.

Dari hasil model 3D (Gambar 4 dan Gambar 5) dapat diketahui terdapat kemenerusan dua zona mineralisasi emas utama yang memanjang arah utara-selatan ditunjukkan dengan garis putus-putus berwarna hitam. Kemenerusan zona mineralisasi emas tersebut dapat terlihat pada Lintasan $B$ hingga Lintasan D, Lintasan F hingga Lintasan I, dan Lintasan $\mathrm{K}$ hingga Lintasan $\mathrm{N}$. Interpretasi kedua zona mineralisasi tersebut sesuai dengan adanya keterdapatan di lapangan zona urat kuarsa yang berpasangan dengan jarak sekitar $250 \mathrm{~m}$ dan panjang $400 \mathrm{~m}$. Kehadiran urat kuarsa yang mengandung mineralisasi tersebut dikontrol oleh struktur sesar yang berada di daerah penelitian.

\section{KORELASI PENAMPANG NILAI RESISTIVITAS SEMUA LINTASAN}

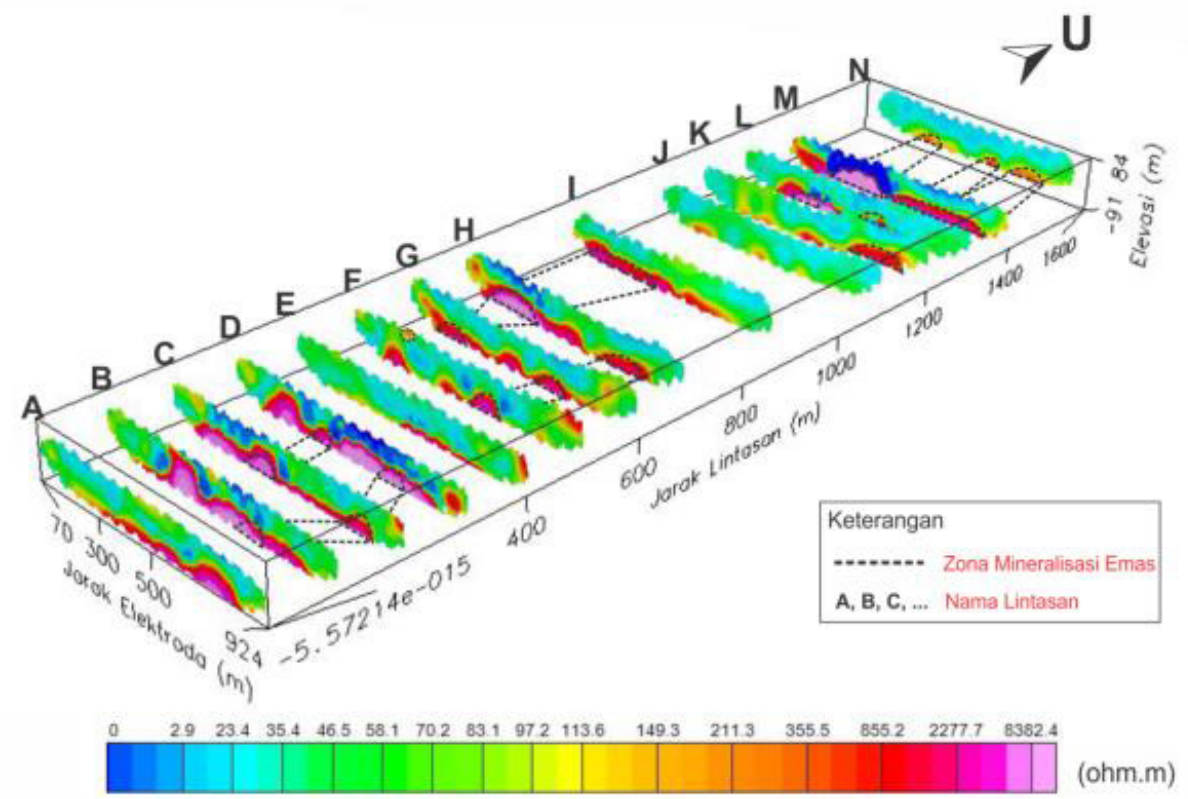

Gambar 4. Hasil korelasi penampang nilai resistivitas dari semua lintasan 


\section{MAKALAH ILMIAH}

Berdasarkan hasil model 3D (Gambar 6) diketahui bahwa volume zona urat kuarsa yang diduga mengandung mineralisasi emas diperkirakan sekitar $519.000 \mathrm{~m}^{3}$.
Perhitungan ini dilakukan dengan cara menghitung volume zona mineralisasi emas yang memiliki nilai resistivitas $>250$ $\Omega \mathrm{m}$ dan chargeability $>300 \mathrm{~ms}$.

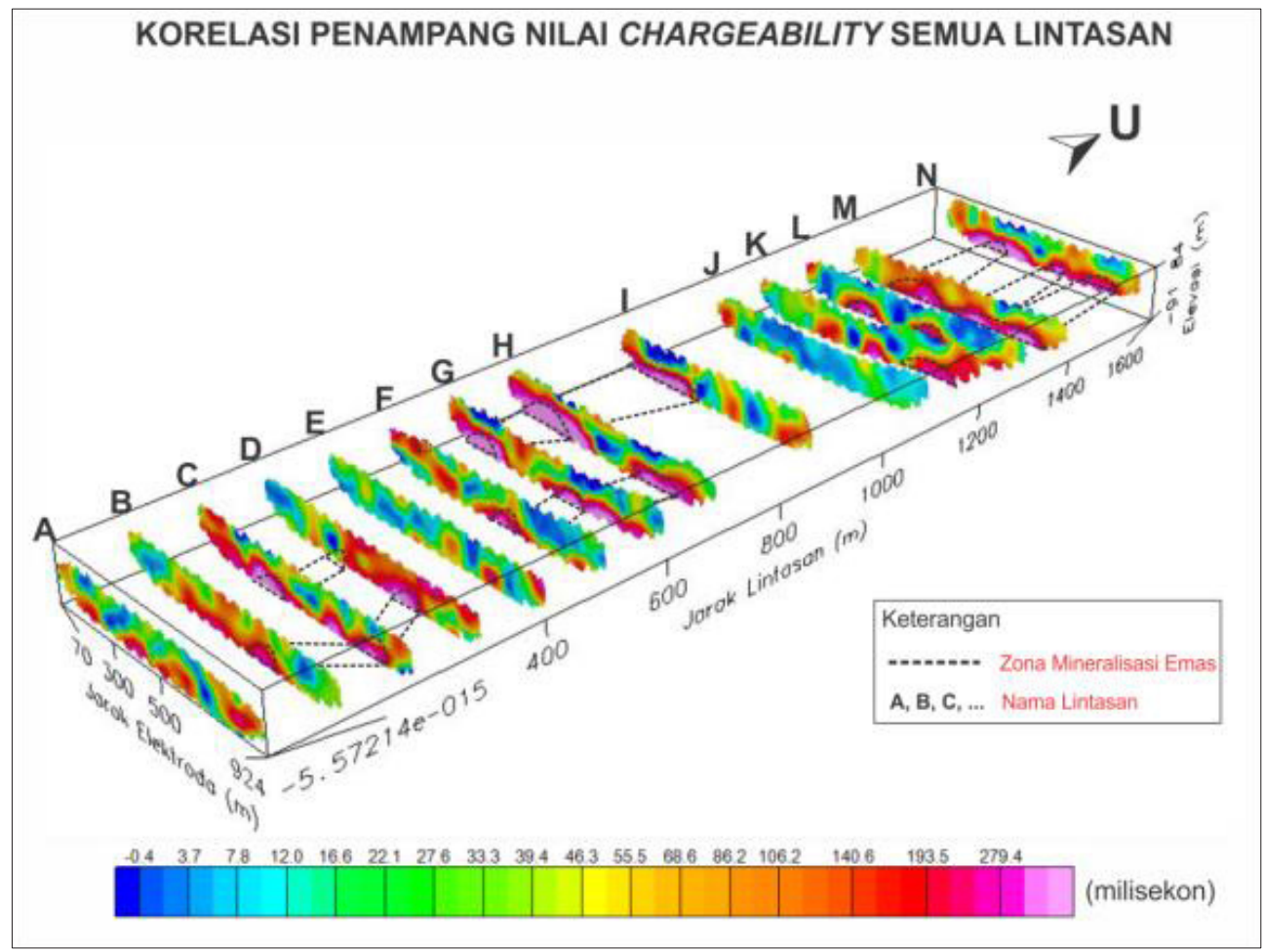

Gambar 5. Hasil korelasi penampang nilai chargeability dari semua lintasan



Gambar 6. Sebaran zona urat kuarsa berdasarkan hasil model 3D 


\section{MAKALAH ILMIAH}

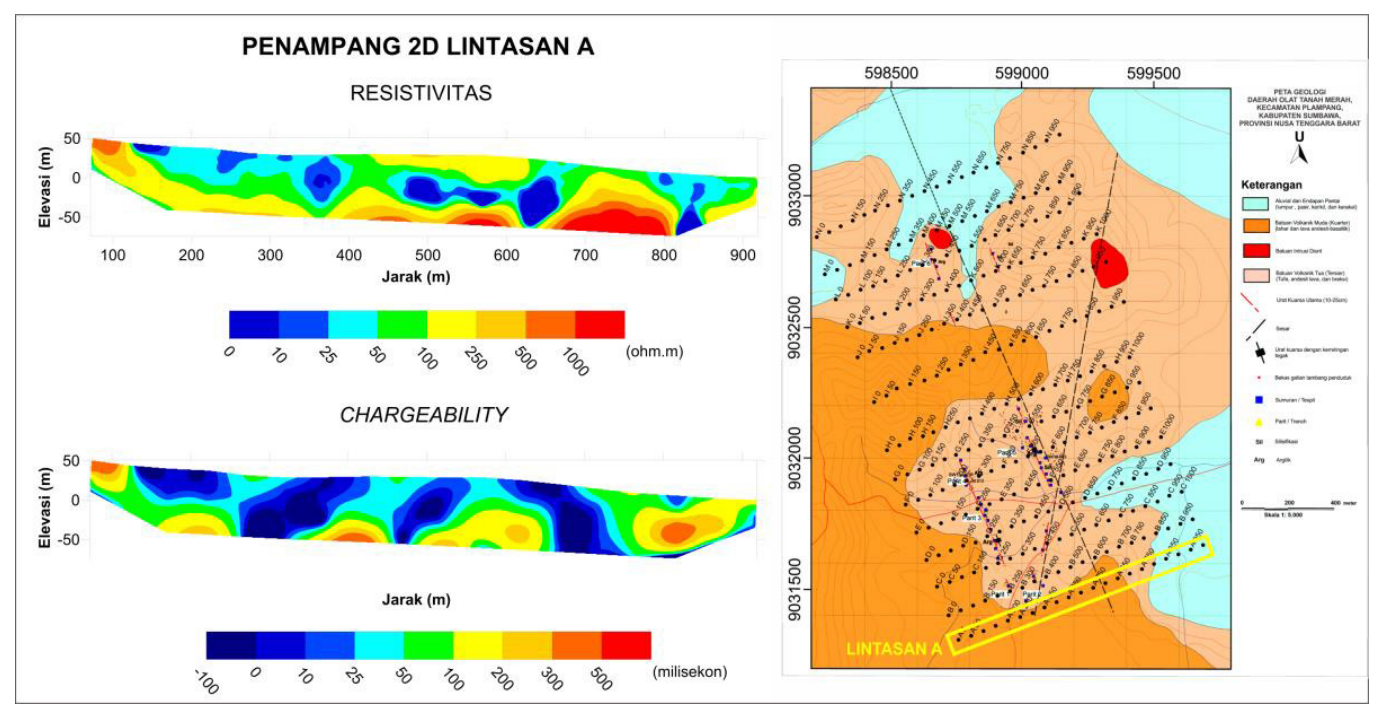

Gambar 7. Hasil interpretasi Lintasan A

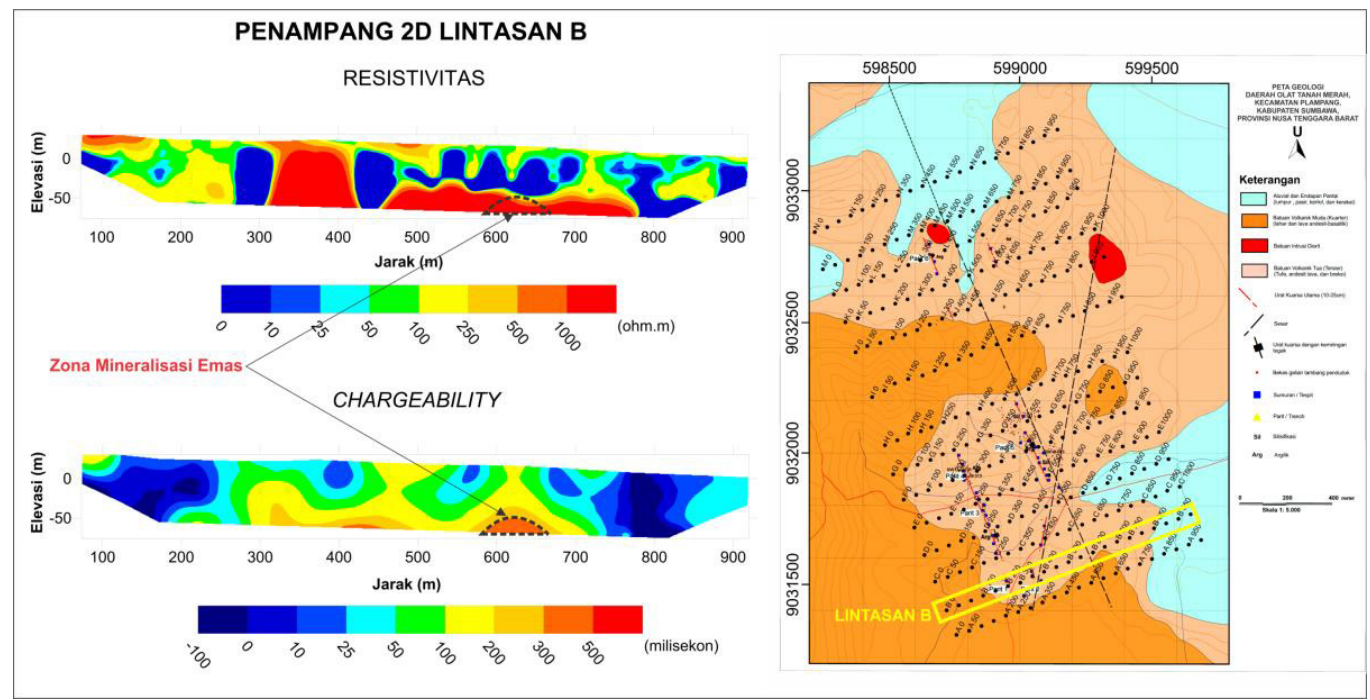

Gambar 8. Hasil interpretasi Lintasan B

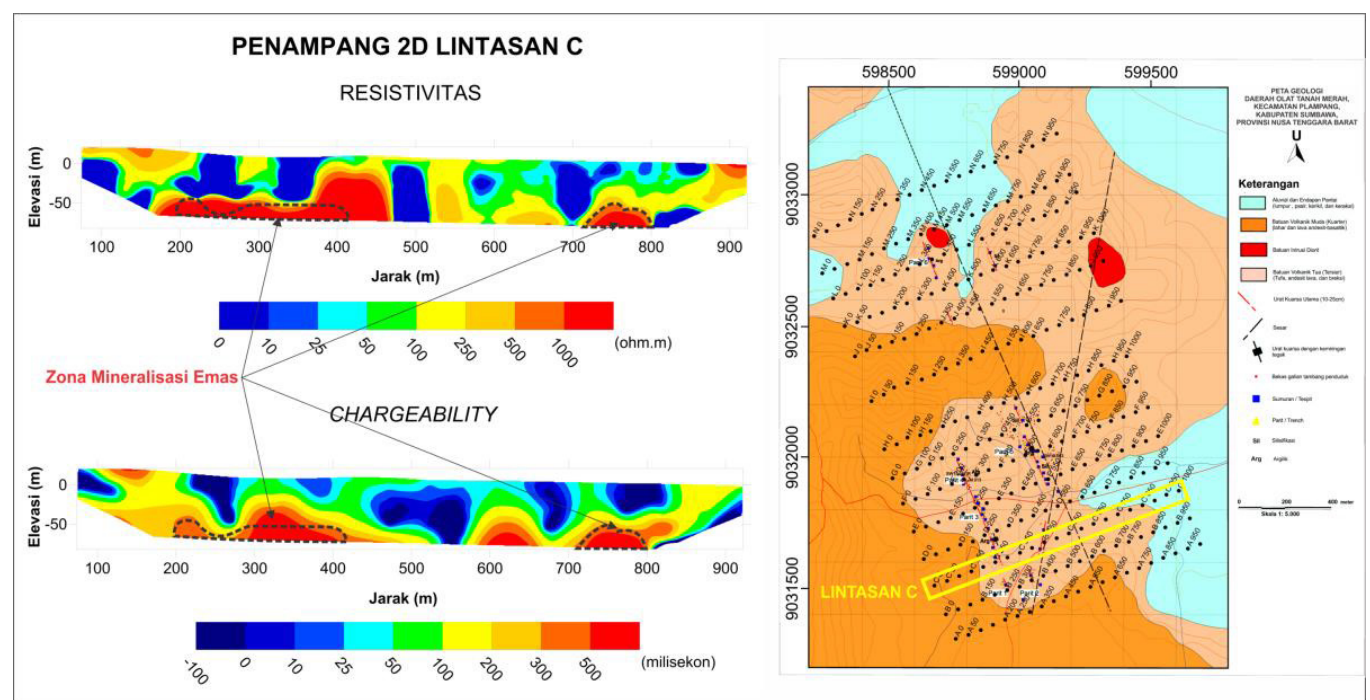

Gambar 9. Hasil interpretasi Lintasan C 


\section{MAKALAH ILMIAH}

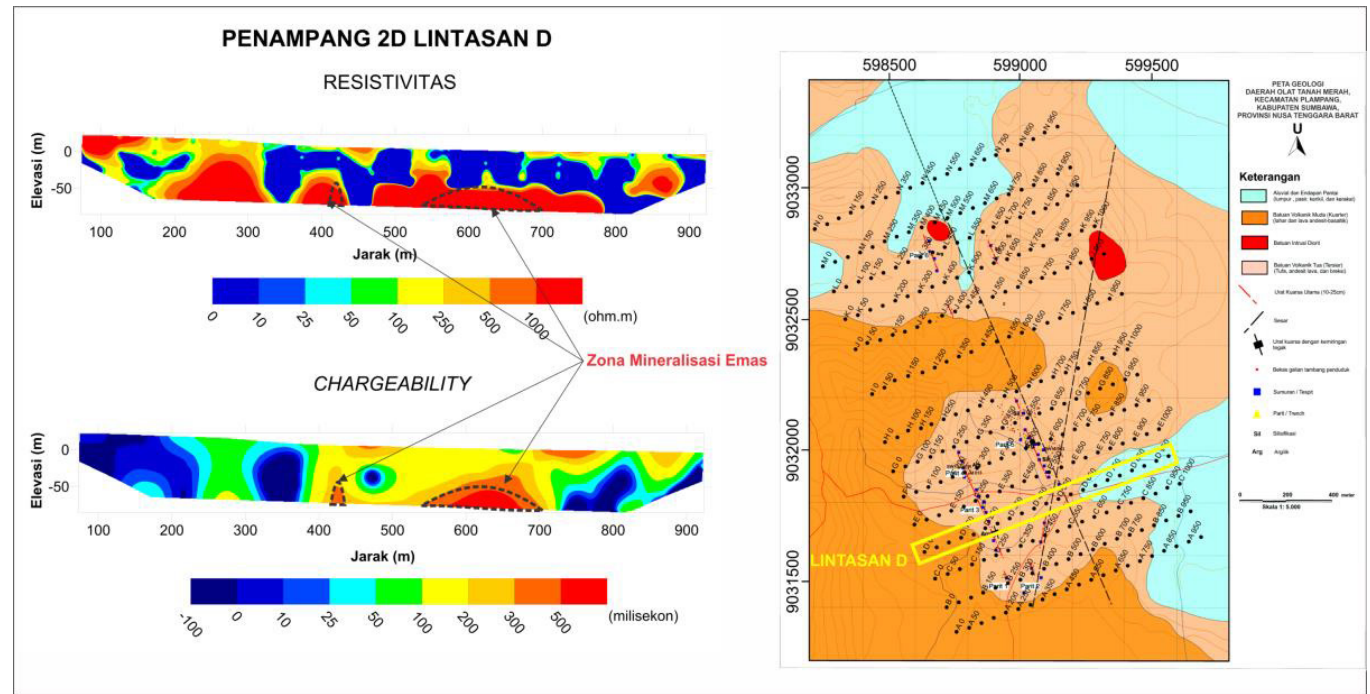

Gambar 10. Hasil interpretasi Lintasan D

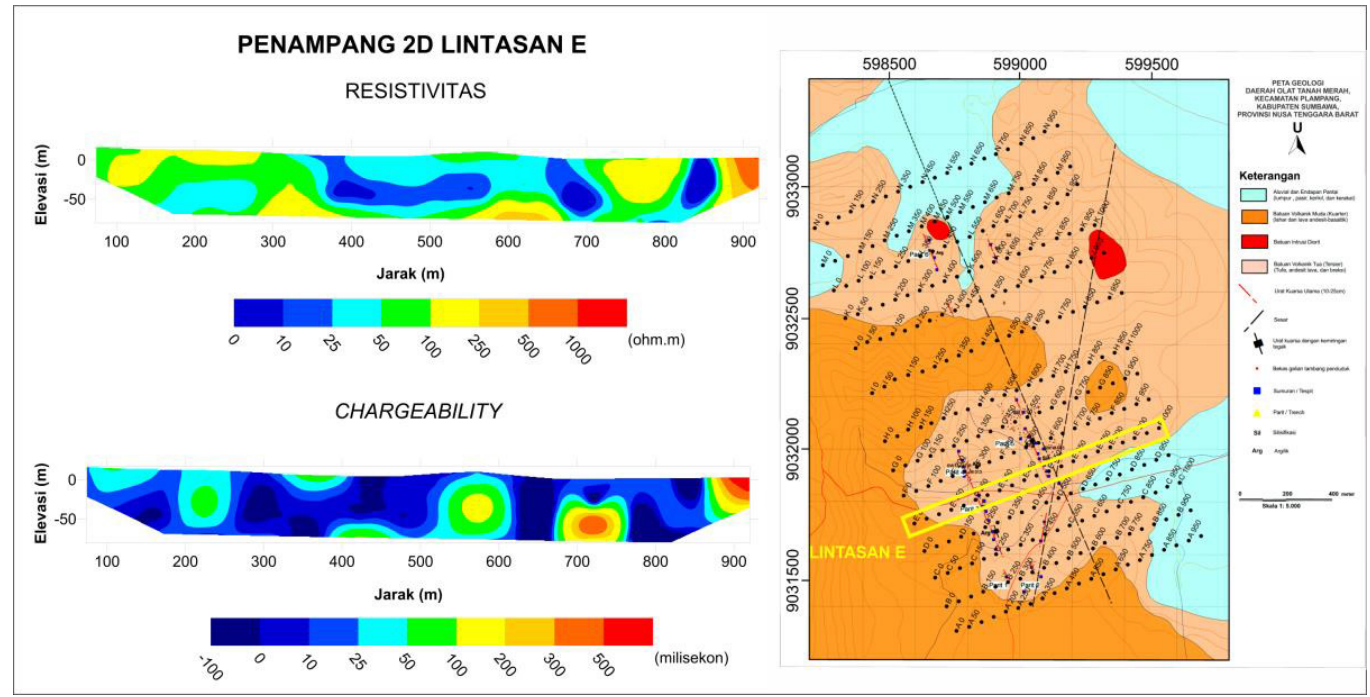

Gambar 11. Hasil interpretasi Lintasan E

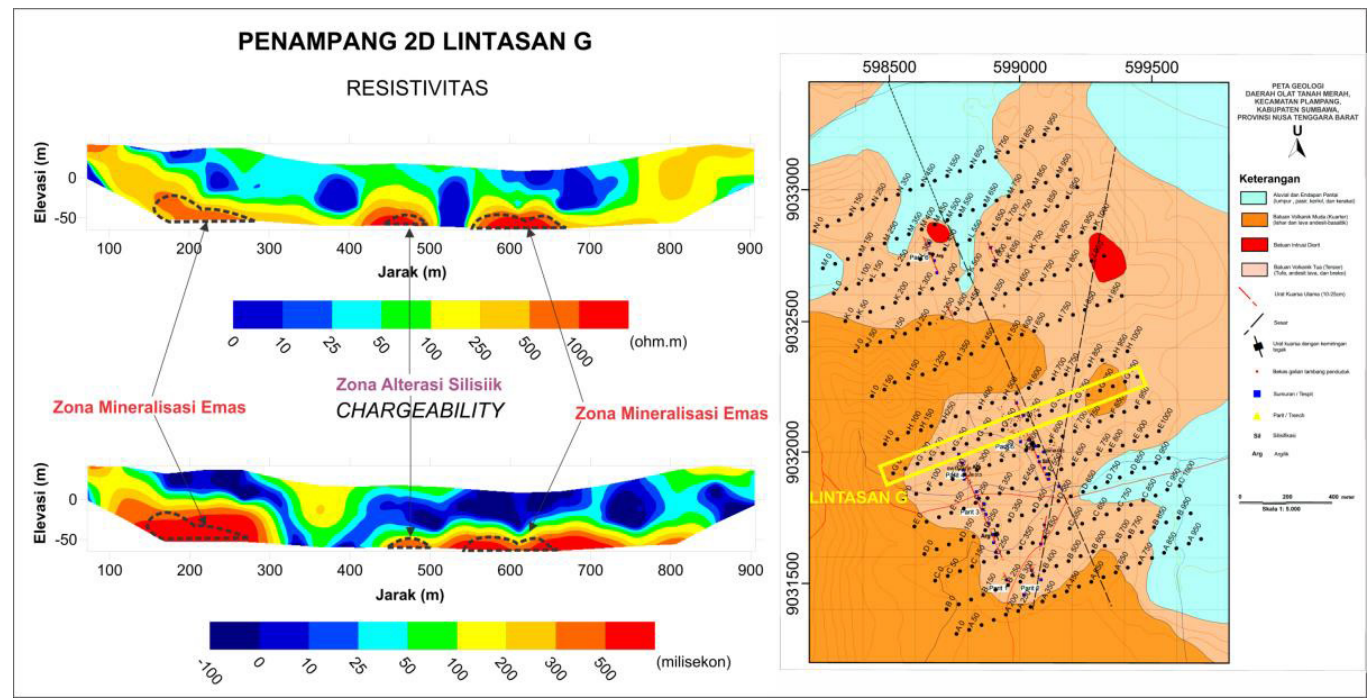

Gambar 12. Hasil interpretasi Lintasan G 


\section{MAKALAH ILMIAH}

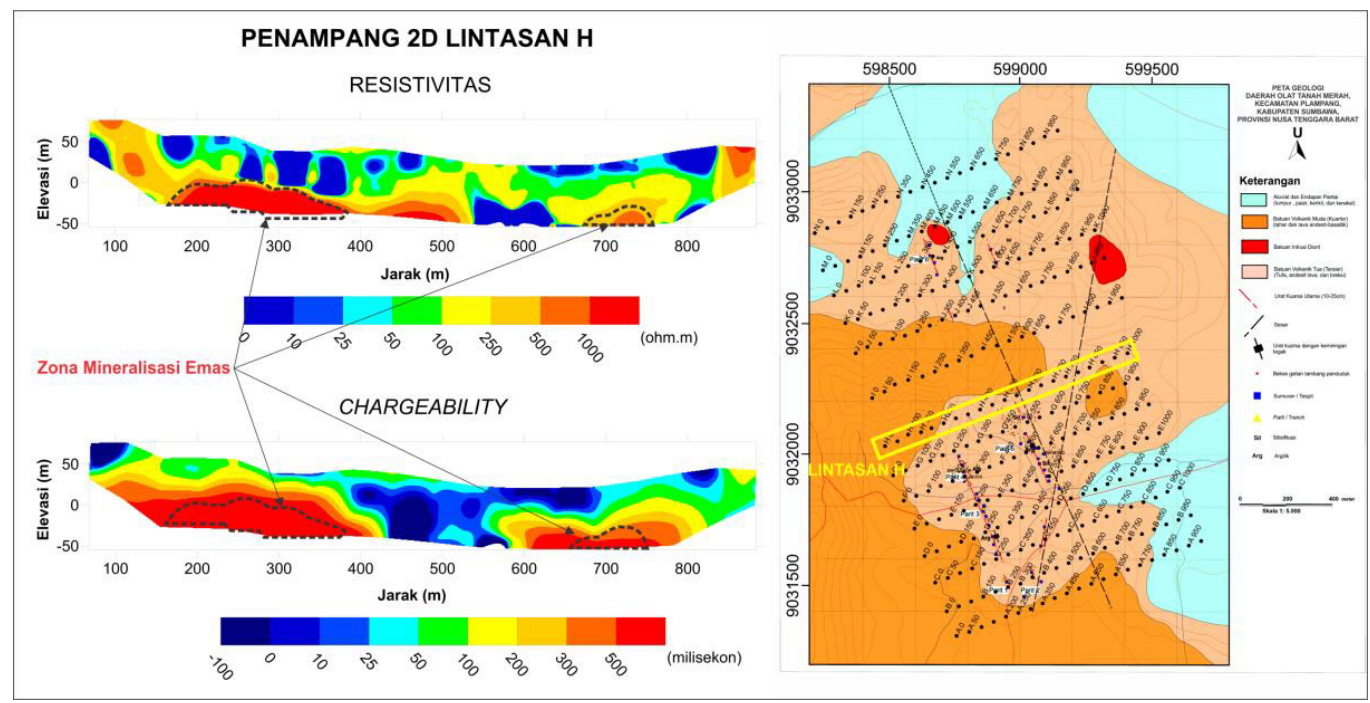

Gambar 13. Hasil interpretasi Lintasan $\mathrm{H}$

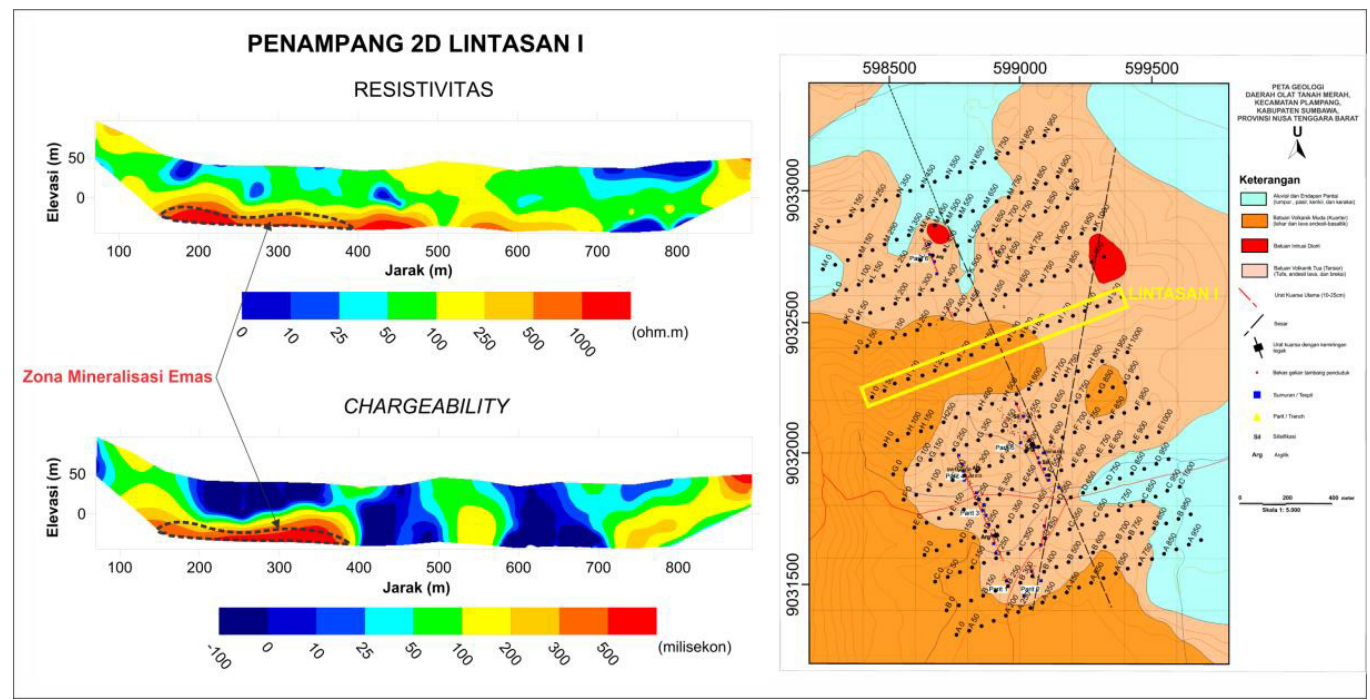

Gambar 14. Hasil interpretasi Lintasan I

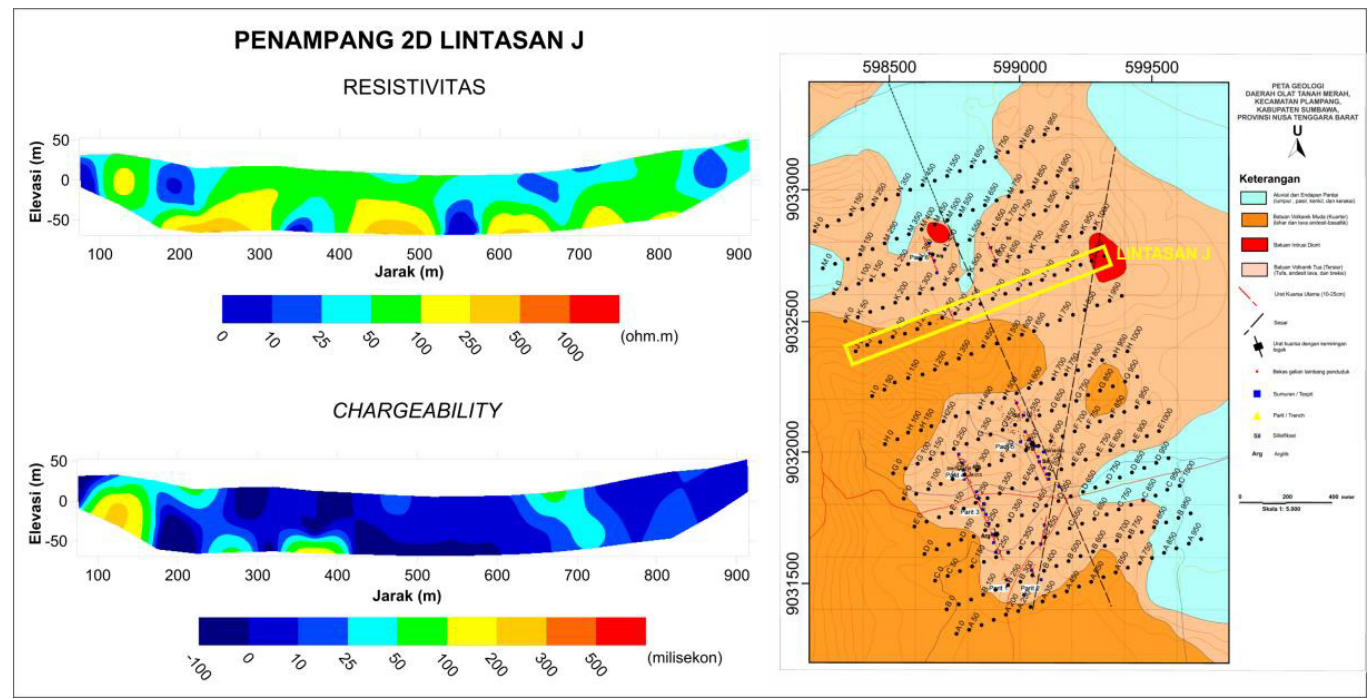

Gambar 15. Hasil interpretasi Lintasan J 


\section{MAKALAH ILMIAH}

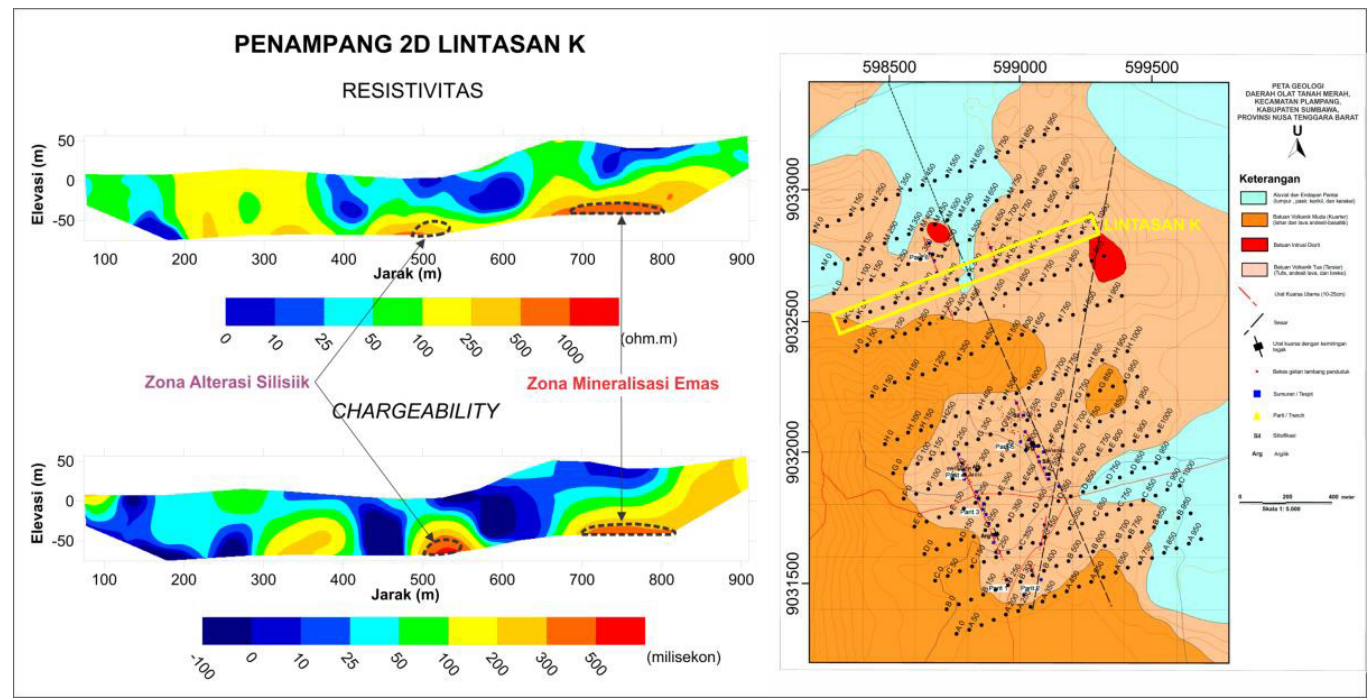

Gambar 16. Hasil interpretasi Lintasan K

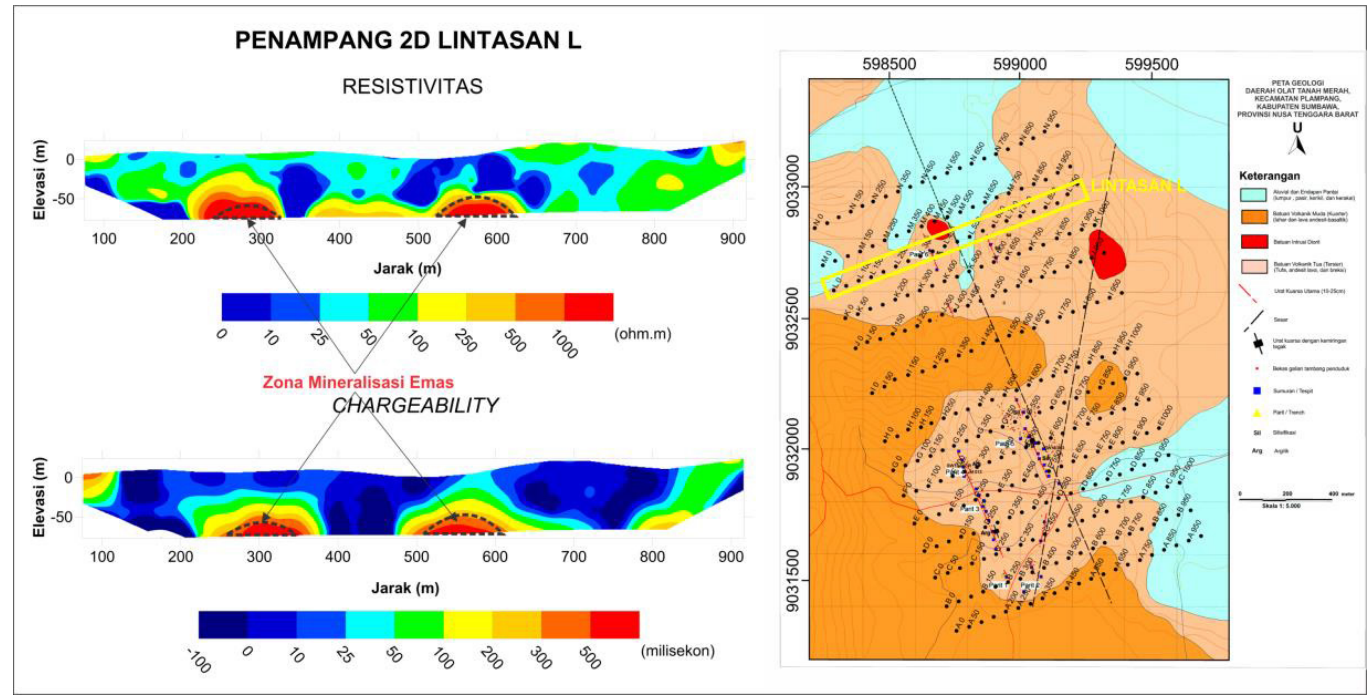

Gambar 17. Hasil interpretasi Lintasan L

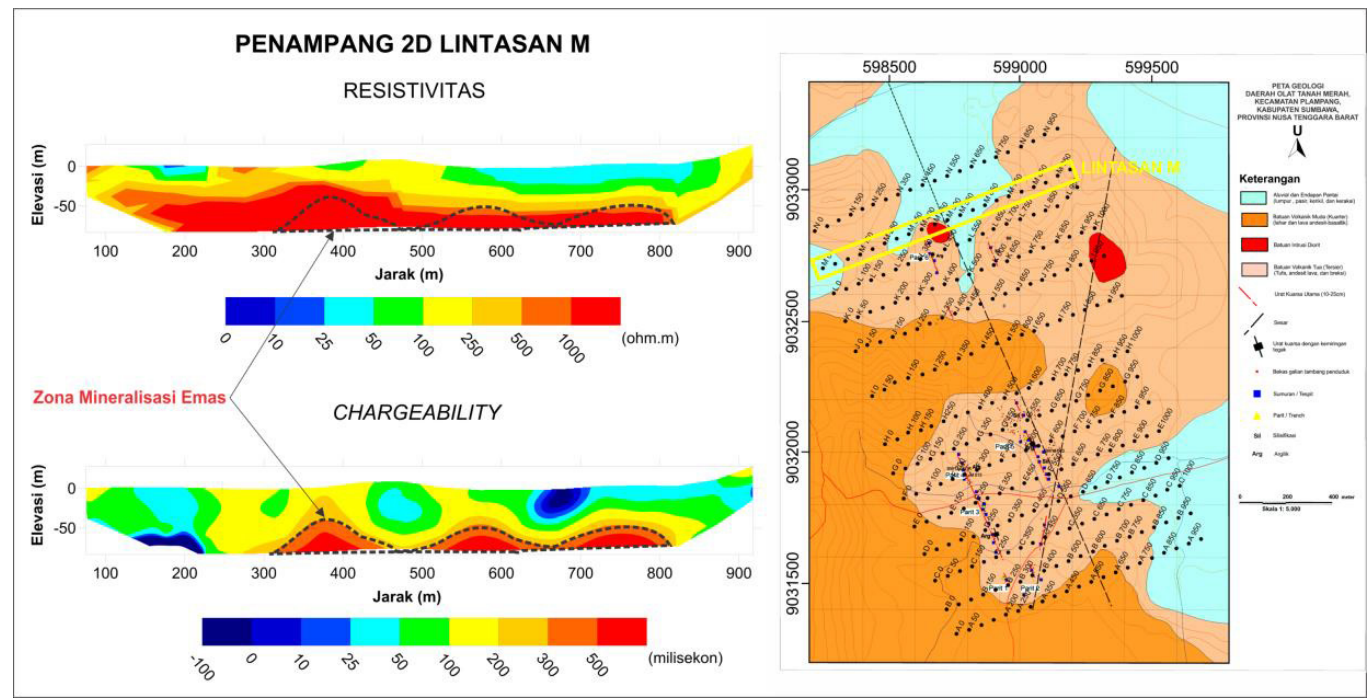

Gambar 18. Hasil interpretasi Lintasan M 


\section{MAKALAH ILMIAH}

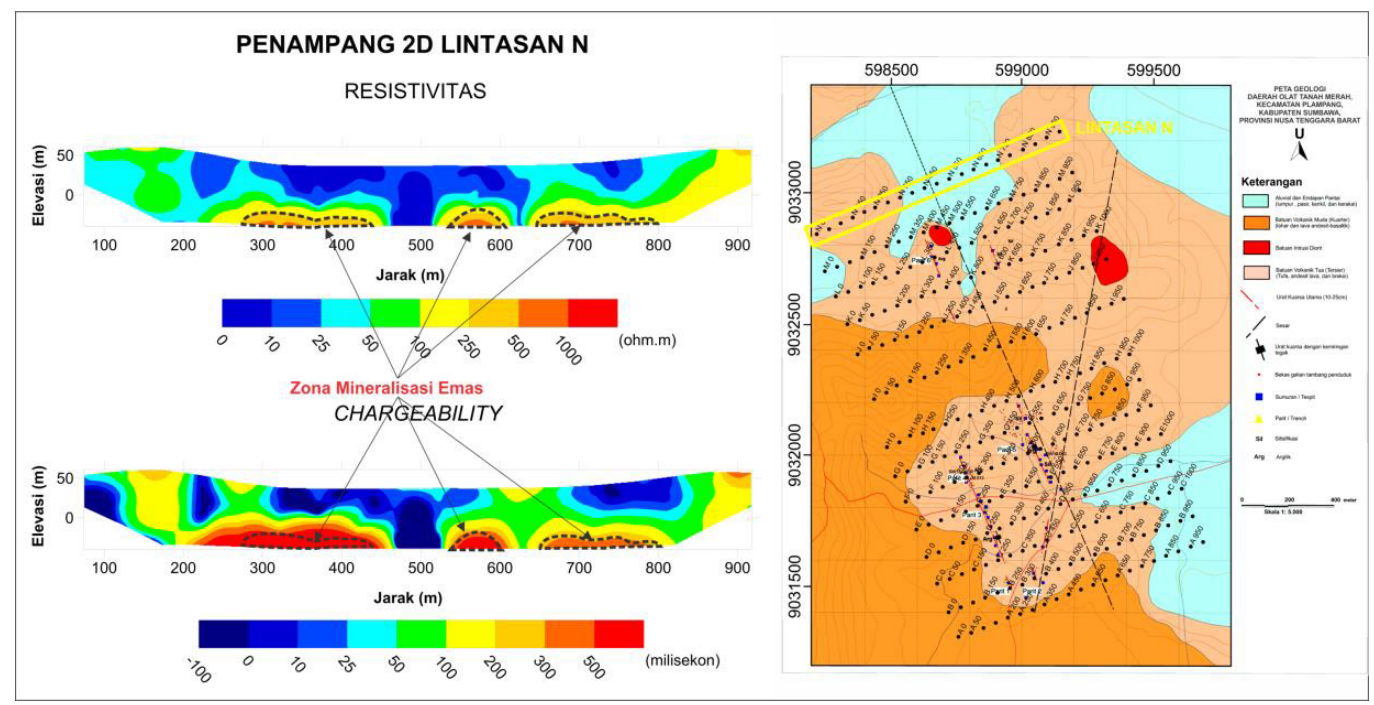

Gambar 19. Hasil interpretasi Lintasan N

\section{KESIMPULAN}

Zona mineralisasi emas di daerah penelitian ditunjukkan dengan nilai resistivitas $>250 \Omega \mathrm{m}$ dan nilai chargeability $>300 \mathrm{~ms}$. Sebaran zona urat kuarsa yang diduga mengandung mineralisasi emas terbagi menjadi dua kemenerusan zona utama yang memanjang arah utara-selatan dengan perkiraan potensi volume sebesar $519.000 \mathrm{~m}^{3}$.

\section{UCAPAN TERIMA KASIH}

Penulis mengucapkan terima kasih sebesar-besarnya kepada Pusat Sumber Daya Mineral Batubara dan Panas Bumi yang telah menyediakan waktu, tempat, dan data untuk melakukan penelitan ini. Penulis mengucapkan terima kasih kepada Dr. Eddy Hartantyo, M.Si., Dosen Prodi Geofisika, Fakultas Matematika dan IImu Pengetahuan Alam, Universitas Gadjah Mada, yang telah memberikan masukan dan bimbingan dalam penelitian ini. Penulis juga berterimakasih kepada semua pihak yang telah membantu sehingga penelitian ini dapat berjalan dengan lancar.

\section{DAFTAR PUSTAKA}

Darman, H. dan Sidi, F.H., 2000, An Outline of The Geology of Indonesia, Ikatan Ahli Geologi Indonesia, Jakarta.

Hamilton, W., 1973, Tectonics of the Indonesian Region, Geological Society of Malaysia, 6 (July), 3-10, Kuala Lumpur.

Moetamar, 2013, Laporan Eksplorasi Umum Logam Mulia di Kabupaten Sumbawa, Provinsi Nusa Tenggara Barat, Pusat Sumber Daya Geologi, Bandung.

Rahmah, S., 2009, Pencitraan Dua Dimensi Data Resistivity dan Induced Polarization untuk Mendelineasi Deposit Emas Sistem Epithermal di Daerah " $X$," Tesis, Departemen Fisika, Fakultas Matematika dan IImu Pengetahuan Alam, Universitas Indonesia, Depok.

Reynolds, J.M., 2011, An Introduction to Applied and Environmental Geophysics, Willey-Blackwell, Chichester.

Sjoekri, A.S., 1980, Application of Geographic Information Systems for Mineral Exploration in Southwest Sumbawa, Indonesia, Tesis, Colorado School of Mines, Golden. 


\section{MAKALAH ILMIAH}

Sudrajat, A., Mangga, S.A. dan Suwarna, N., 1998, Peta Geologi Lembar Sumbawa, Nusa Tenggara Barat Skala 1: 250.000, Pusat Penelitian dan Pengembangan Geologi, Bandung.
Supriyanto, 2007, Analisis Data Geofisika: Memahami Teori Inversi, Departemen Fisika, Fakultas Matematika dan IImu Pengetahuan Alam, Universitas Indonesia, Depok.

Telford, W.M., Geldart, L.P. dan Sheriff, R.E., 1990, Applied Geophysics, Cambridge University Press, Cambridge.

$\begin{array}{ll}\text { Diterima } & : \text { 22 Januari } 2018 \\ \text { Direvisi } & : 14 \text { Maret } 2018 \\ \text { Disetujui } & : 19 \text { April } 2018\end{array}$

